\section{PRODUCTION}

ENGINEERING ARCHIVES
2016, Vol. 13, No. 4, pp 49-52

ISSN 2353-5156

ISSN 2353-7779 (print version)

(online version)

\title{
The OHS management system in the "small-sized" production company
}

\author{
Dorota Klimecka-Tatar ${ }^{1}$, Marta Niciejewska ${ }^{2}$ \\ ${ }^{1}$ Czestochowa University of Technology, ul. Dabrowskiego 69, 42-200 Czestochowa, Poland, e-mail: klimt@wip.pcz.pl \\ ${ }^{2}$ Czestochowa University of Technology, ul. Dabrowskiego 69, 42-200 Czestochowa, Poland, e-mail: marta.n@ vip.onet.pl
}

Abstract. In the article the problem with systemic management of safety in the smallest production entities has been shown. The effect of health and safety management system and the benefits resulting from it for the most numerous economic entities in Poland - microenterprises have been discussed. Moreover, the results of questionnaire examination conducted in several Polish production companies have been presented. Surveys were completed in companies in which the number of employees does not exceed 49 people (micro enterprise - from 1 to 9 employees and small enterprises - from 10 to 49 employees).

Key words - health and safety management system, micro enterprises 'small size', a manufacturing company

\section{Introduction}

The Occupational Health and Safety Management System is an autonomous part of the overall enterprise management system. It consists of the following elements: the organizational structure, planning, responsibilities, policies, procedures, processes and resources needed for development, review of health and safety policy etc. (pkt. 3.2. PN-N 18001:2004). These are all elements that are used to establish the policies and objectives of the company in the field of occupational safety and health and also tools which are used to achieve those objectives.

Basic requirements for the occupational health and safety management system's in the company resulting from legal regulations under which it is necessary to carry out a risk assessment and resulting from this assessment protection measurement, as well as employees training (KORADECKA D. 2008).
In Poland, among entrepreneurs the most popular consistently is PN-N18001 Standard. Continuous improvement of working conditions, which is the overarching objective of health and safety management system ensures to the employee, that the employer cares about his safety in the performance of professional duties (ULEWICZ R. ET AL. 2015).

Implementation of OHS management system according to PN-N-18001 can not only help to meet the requirements of applicable law, but also enable the achievement of measurable benefits associated with the improvement of the level of occupational health and safety (PODGÓRSKI D. 2015).

An effective occupational health and safety management system allows to (EJDYS J. ET AL. 2013):

- reduce the number of accidents at work as well as the number of occupational diseases and related losses,

- reduce employees' absenteeism,

- increase productivity, 
- improve the quality of work.

According to literature, there are sufficient five steps to build the company effective health and safety management system complying with the requirements of PN-N-18001. It is also possible in 'small size' companies, which are considered to be a actuating medium of economic growth and supporting innovation in Europe.

\section{Methodology of research}

This article contains brief reviews of some literature, as well as results from available reports about the importance of occupational health and safety management system in small businesses, especially manufacturing companies. The operation of safety management system in "small size" enterprises producing furniture using the original questionnaire has also been evaluated.

\section{Results and discussions}

The SME sector in the EU employs the average of 4.22 people, which decisive majority $(92.4 \%)$ of enterprises in the EU is classified as a micro-enterprise. These micro-enterprises represent $67.4 \%$ of all jobs in Europe. Therefore, their importance for the European economy is significant. The data shows that workers in small-sized businesses are more at risk than employees of larger businesses and smaller enterprises confronted with more problems in risk control.

Various studies, including those carried out by EU-OSHA's - European Survey of Enterprises on New and Emerging Risks (ESENER), show that difficulties in meeting the requirements of occupational health and safety are particularly important in smaller entities (www.osha.europa.eu of 10.10.2016).

The relatively low level of occupational health and safety can result from certain characteristics typical of small businesses, such as structural and organizational characteristics of work and employment in such entities, their economic situation and economic relations, diversity and flexibility of business, small regulatory oversight of these companies, attitudes and competence of owners and employees in small entities or their short-term operations. These features make it difficult for micro-businesses and small-businesses to create and maintain a safe and healthy work environment. Among other factors that have an impact on the management of occupational health and safety in these companies (compared to larger companies) are the following (www.osha.europa.eu of 10.10.2016):

- difficulties with regulation, since they are generally not uniform, geographically dispersed and without coherent representation,

- budget constraints, often resulting in the lack of resources to implement initiatives and interventions in the field of occupational health and safety related to getting of paid advice and information on occupational health and safety, as well as use of specialized tools and controls,

- inadequate resources make it impossible to implement of preventive measures,

- less time and energy is devoted to the task "noncore activities", and as such are sometimes considered the activities in the field of safety and health. Appropriate level of occupational health and safety is not considered as a priority,

- risk assessment is sometimes expensive and inconvenient, especially if the company does not have the resources or knowledge in the field of occupational health and safety, which enable it to effectively carry out,

- organizations promoting or enforcing appropriate level of occupational health and safety is sometimes difficult to immediately reach out to micro and small enterprises.

While a "small size" company actually has a lot of difficulties in the application of health and safety management system in their structures, it certainly has many benefits. As the most important and most frequently mentioned by employee the lack of employee awareness of the importance of the health and safety management system and conviction of the lack of financial resources for the implementation of the system principles are listed. In addition, employees of "small size" enterprises, especially micro-enterprises, do not indicate safety as the most important value. It is for them secondary. As the most important considered for the enterprise are maintaining in the market and be competitive. However, there are enterprises (employing 10 to 49 employees - small enterprises), for which their company's success sis the safety system management. They indicate the following benefits of occupational health and safety management system:

- increase the compliance of the legal requirements,

- increase employee awareness of the rules and safety regulations,

- minimization of the accidents' incidence.

A very important and fundamental goal of health and safety management system in the enterprise is the 
principle of continuous improvement based on the Deming Cycle (Fig. 1).

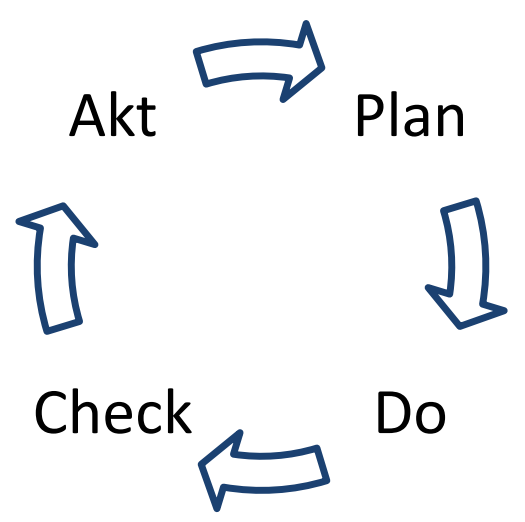

Fig. 1. Deming cycle model (LIKER J. K., FRANZ J. K. 2013).

These four basic steps - plan, do, check, act - are the strategic elements of the work security policy. Contrary to the opinions of the respondents, it can be easily implemented, even in the smallest entities, especially productive. The company should always plan for all its activities on the market, then realize the planned activities, then check the validity of objectives made and correct everything that needs correcting. It is very important that the workers in of this type of action considered the norm, and they saw the sense in continuous improvement.

To ensure a comprehensive system, organizations introducing a health and safety management system can (and should) use the guidelines at international, national and industry levels. The structure of the system structure has been shown in Fig. 2.

The implementation and operation of the $\mathrm{OSH}$ management system is closely related to workers' knowledge on the security and management system. While employees of small businesses (10 to $49 \mathrm{em}$ ployees) declared in the questionnaire the knowledge of basic health and safety regulations. They also respect safe behavior at work. Conversely, the employees of micro-enterprises (up to 9 employees)did not declare such knowledge. Most respondents perceive the lack of knowledge about safe work as "boring" and irrelevant as they usually did not participate in training or participated with constraint.

It should be remembered that every employer (manager represented often micro enterprises) is responsible for the initial training carried out; periodic as well as instructional. Moreover, the owner is liable for any problems resulting from their low level training, or even its absence, regardless of the extent of accidents; whether they are minor or produce fatal consequences.

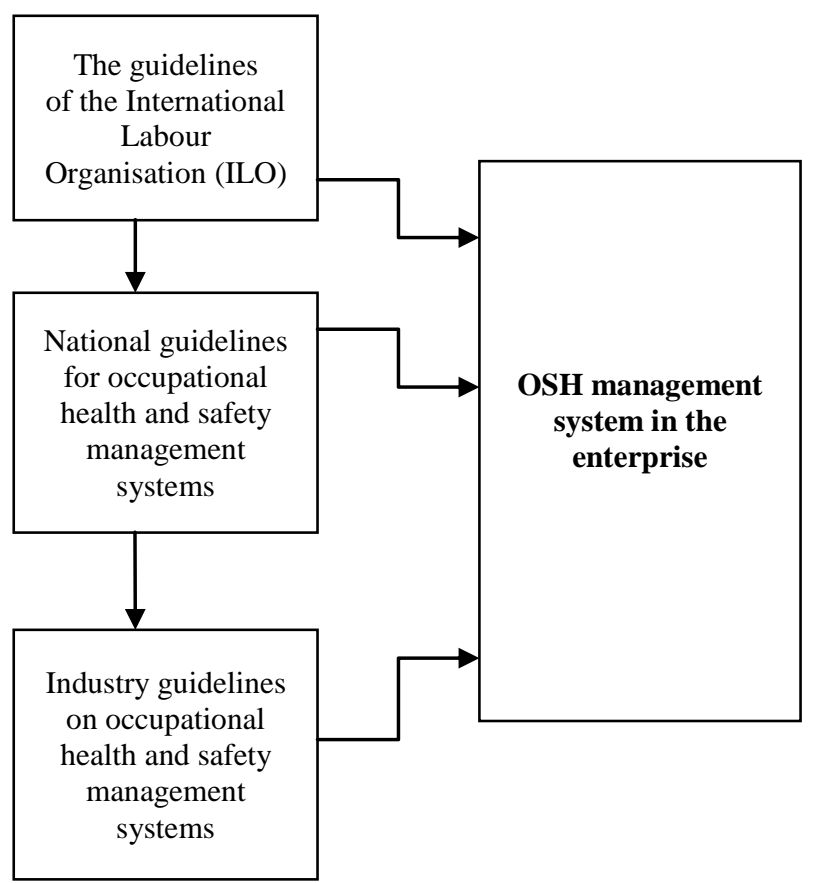

Fig. 2. The structures element of Occupational Health and Safety Management System (GALUSZA M. 2014).

\section{Summary}

System management of health and safety in "small size" enterprises is difficult but not impossible. In medium and large business entities, there are health and safety departments that care about all the elements of health and safety management system that shape the consciousness of their employees in terms of safe and accident-free work, pointing to the benefits of a comprehensive and systematic approach to managing health and safety. In small entities, especially micro-enterprises, there is the lack of supervisors' knowledge and awareness that the system management of health and safety is not complicated and expensive, and brings many benefits. Literature and safety experts suggest that the most neglected element that are responsible for the functioning of the OHS management system are "training, awareness, competence and motivation" (LEWANDOWSKI J., GÓRSKA E. 2010). A human being, as the most important element in any organization, and the most valuable capital should be adequately trained, his awareness should be shaped, competence raised and motivation for safe and accident-free operation is still activated. 
Responsibility for all the above mentioned elements shall be borne by supervisor, who in micro enterprises, which is usually also the owner of the company. It also builds on relationships in the enterprise, as the employees perceive their mentor and leader. Regardless of the size of the economic entity and the (AAMIR ALI CHUGHTAI 2015). Nature of the business, one of the most important elements that determine the effectiveness of the OHS management system is the human factor.

\section{Literature}

1. Aamir Ali Chughtai 2015. Creating safer workplaces: The role of ethical leadership. Vol. 73, pp. 92-98

2. EJdys J., KobYlińsKa U., LULEWICZ-SAS A. 2013. Zintegrowane systemy zarzadzania jakościa, środowiskiem $i$ bezpieczeństwem pracy. Oficyna Wydawnicza Politechniki Białostockiej, Białystok.

3. EU-OSHA - raporty, www.osha.europa.eu

4. Galusza M. 2014. Poradnik stużby BHP. Wyd. Tarbonus, Kraków-Tarnobrzeg.

5. KoRADECKA D. 2008. Bezpieczeństwo i higiena pracy, Wyd. CIOP-PIB, Warszawa.

6. LEWANDOWSKI J., GÓRSKA E. 2010. Zarzadzanie i organizacja środowiska pracy. Oficyna Wydawnicza Politechniki Warszawskiej, Warszawa.

7. LIKER J. K., FRANZ J. K. 2013. Droga Toyoty do ciagtego doskonalenia. Wyd. MT Biznes, Warszawa.

8. PODGÓRSKI D. 2015. Measuring operational performance of OSH management system - A demonstration of AHP-based selection of leading key performance indicators. Safety Science Vol. 73. pp. 146-166

9. Ulewicz R., Klimecka-Tatar D., Mazur M., NICIEJEWSKA M. 2015. Wybrane aspekty zarzadzania bezpieczeństwem i higiena pracy. Oficyna Wydawnicza Stowarzyszenia Menedżerów Jakości i Produkcji, Częstochowa. 